\title{
THE ASSOCIATION BETWEEN PERSONAL HYGIENE, HOUSE ENVIRONMENTAL SANITATION, AND WORM INFESTATION IN ELEMENTARY SCHOOL CHILDREN, PADANGSIDEMPUAN, NORTH SUMATERA
}

\author{
Juliana Rezki, Nurmaini, Fazidah Aguslina Siregar \\ Masters Program in Public Health, Universitas Sumatera Utara
}

\begin{abstract}
Background: Intestinal worm infestation is a global health issue. Soiltransmitted helminth (STH) infections form the most important group of intestinal worms affecting two billion people worldwide, causing considerable morbidity and suffering, though entirely preventable. This study aimed to estimate the association between personal hygiene, house environmental sanitation, and the risk of worm infestation in elementary school children.
\end{abstract}

Subjects and Method: This was a cross-sectional study conducted at public elementary school, Pudun Julu, Batuandua, Padangsidempuan, North Sumatera, from November to December 2017. A sample of 108 students was selected from the source population of 237 students attending the elementary school in Pudun Julu. The dependent variable was worm infestation. The independent variables were personal hygiene and house environmental sanitation. The worm infestation was examined by feces in laboratory. The other data were collected by questionnaire. The data were analyzed by a multiple logistic regression.

Results: The risk of worm infestation increased with poor personal hygiene (OR $=3.86 ; 95 \% \mathrm{CI}=1.29$ to $11.53 ; \mathrm{p}=0.026)$ and poor house environment sanitation $(\mathrm{OR}=2.84 ; 95 \% \mathrm{CI}=1.19$ to $6.81 ; \mathrm{p}=0.031)$.

Conclusion: Poor personal hygiene and poor house environment sanitation personal hygiene increases the risk of worm infestation.

Keywords: worm infestation, personal hygiene, environmental sanitation

\section{Correspondence:}

Juliana Rezki. Masters Program in Public Health, Universitas Sumatera Utara. Email: julie_hutapea@gmail.com. Mobile: 082370068743. 